\title{
Local e-Government in the Netherlands: From Ambitious Policy Goals to Harsh Reality
}

Ronald Leenes 


\title{
Local e-Government in the Netherlands: From Ambitious Policy Goals to Harsh Reality
}

\section{Ronald Leenes}

Tilburg University,

TILT - Tilburg Institute for Law, Technology, and Society

Tilburg, The Netherlands, r.e.leenes@uvt.nl

\section{Keywords}

e-Government, e-Government policy, electronic service delivery, public service delivery maturity, the Netherlands

\begin{abstract}
The Netherlands took up e-Government development relatively early and was considered to be one of the leading nations in e-Government developments. In recent years, it has slipped back in the various international benchmarks, and also other signs show that the country no longer is at the front of e-Service development. This paper discusses possible causes for the decline of Dutch eService delivery development. Important factors in the explanation can be found in the structure of the Dutch public sector which can be characterized as fairly decentralized. The central government sets ambitious policy goals, but lacks the means to have them realized on the local level which is the primary level at which public service delivery takes place. The municipalities on the other hand are incapacitated by relatively small scale, the large number of services they provide and the lack of real incentives to move service delivery online. As a result, e-Service development on the local level is inefficient and progresses relatively slow. There are signs though that things are changing: the central government takes on a more active stance, and local authorities join forces to develop services together.
\end{abstract}

(c) IT/A - Institute of Technology Assessment

of the Austrian Academy of Science

A- I 030 Vienna, Strohgasse 45/5, Fax: +43-I-7I0 9883

http://www.oeaw.ac.at/ita/

ISSN 1681-9187 


\section{Content}

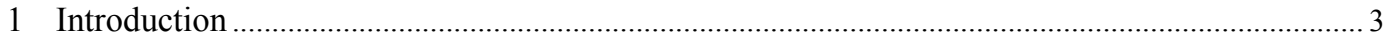

2 A brief history of electronic service delivery in the Netherlands .................................................. 3

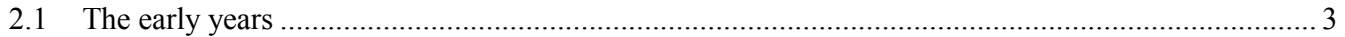

2.2 OL2000

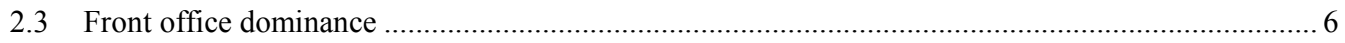

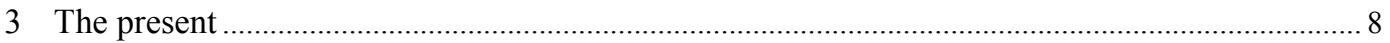

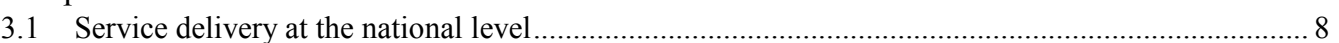

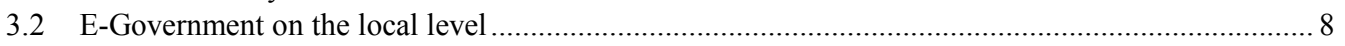

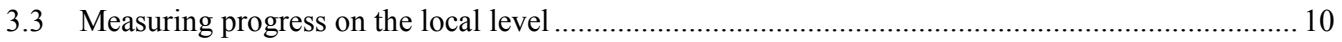

3.4 The Netherlands compared to other EU countries............................................................................. 11

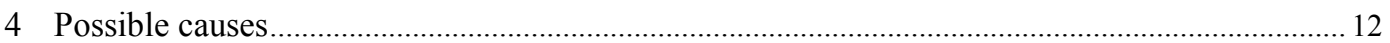

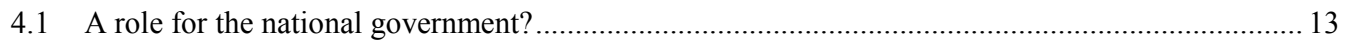

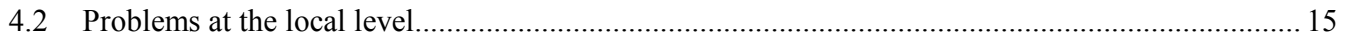

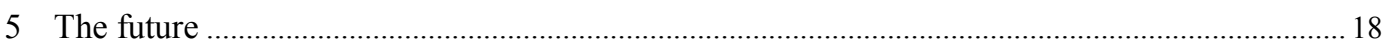

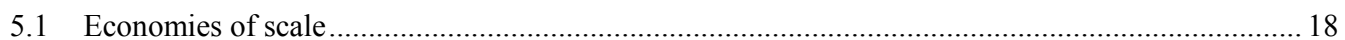

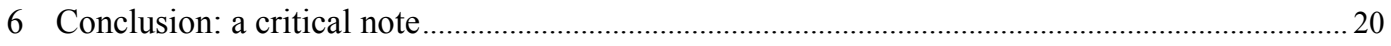

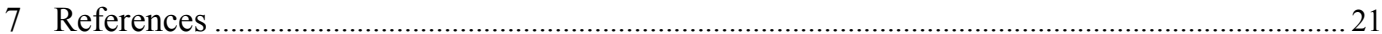




\section{Introduction}

The Netherlands took up e-Government development relatively early, in the first half of the 1990s, and from a favorable starting position as Kate Oakley observed in 2000 in a comparison of some seven forerunners in e-Government (Oakley 2000). The Netherlands had a good telecommunications infrastructure; almost every household had a telephone connection. Internet penetration was high among its citizens, partly due to the newly introduced free serve internet model by some internet service providers. PC ownership is very common among employees as a result of tax benefits for the purchase of PCs through employers. Almost every Dutch citizen over 18 years of age has a bank account (unlike in some other countries, such as the UK, where a much smaller percentage of the population has one). The government has relatively well organized official records, such as the Municipal Personal Records Database (in Dutch: GBA), and Dutch citizens trust their government. These are all factors facilitating e-Government development.

The swift uptake of e-Government led to rankings in the top of Europe at the end of the 1990s. More recent years, however, have seen a steady decline of the country's position in international benchmarks. At present, it ranks below the average in Europe in some studies (CGEY 2004). Although one has to be careful to draw conclusions on the basis of international benchmarks, there is reason to believe that the Netherlands indeed is not among the top performers with respect to online, or transactional, services. Why are the Dutch slipping? Have they already reached the ceiling and is progress no longer possible? Or are they simply not doing as well as other European countries? If so, what has caused these changes in relative development? This paper tries to give an answer to some of these questions.

\section{A brief history of electronic service delivery in the Netherlands}

\section{I The early years}

The Dutch e-Government history can be traced back a long time, since ICT use within government, such as tax form processing by the tax authorities, is essentially e-Government. Government from early on acknowledged the importance of using IT to handle large volume services, such as tax returns, student grants and loans, and housing benefits. For this purpose, large computer centers were established in the 1960s, such as the Rijks Computer Centrum (Central Government Computer Centre) in Apeldoorn, which was the central back-office responsible for the collection and administration of taxes.

These developments took place before the term e-Government was introduced in the beginning of the 1990s. ${ }^{1}$ E-Government, especially in the early days was associated with service delivery to citizens. Here history started around 1990 with a project called 'Government Service Centres'. This project,

1 The term is sometimes attributed to US vice president Al Gore who introduced or at least popularised the notion in his white paper 'Reengineering Government through IT' (Office of the vice president 1993). 
like many other e-Government projects, was initiated by the Ministry of the Interior and Kingdom Relations $(B Z K)$, which acts as the coordinating ministry in this respect. An important motivation to start this project was the fragmented nature of Dutch public service delivery. The Netherlands is a densely populated social welfare state in which many government services for the less advantaged exist, but also many obligations and restrictions for which exceptions can be granted. As a result, there is a large number of services, covering both rights and obligations. These services are conceived, developed, and delivered by a plethora of public agencies organized in and around the various policy sectors. For citizens in disadvantaged positions, such as unemployed single parents, this means that, although there are many types of benefits, citizens have to have a reasonable amount of bureaucratic competence. They have to be aware of the services, their providers, and their procedures. They also have to go from pillar to post to obtain all the subsidies and grants they are entitled to. The same is true for the entrepreneurial minded, who also have to know their way in the public sector to meet their obligations. Starting a business requires obtaining a large number of permits from an equally large number of organizations.

The main idea behind Government Service Centres project was to experiment with integrated forms of service delivery in one-stop shops. These service outlets were initially thought to be physical service desks, but IT support for the staff at these desks was envisioned. A strong reliance on IT support was a necessary consequence of combining services in a one-stop shop: the people operating these offices could hardly be expected to be experts on all areas covered by their integrated office.

The improvement of service delivery through integration of services was placed higher on the agenda in 1995 when a policy white paper (BIOS-3) called 'Terug naar de toekomst' ${ }^{2}$ was presented by the Ministry of the Interior (BZK 1995). Whereas the first and second policy white papers on Informatization in the Public Sector (BIOS-1 and BIOS-2) mainly addressed IT within government operation, this third paper explicitly addressed IT use in the relation between government and society. It provided the foundation for online service delivery. An important aim in the BIOS-3 white paper was the reduction of fragmentation by integrating services that, from the citizen's perspective, are related. To this end, the term 'demand pattern' was coined. This resembles the idea of a 'life event' that came to be used around the world slightly later. In BIOS-3, and especially in the OL2000 project it generated, the notion of demand-pattern driven service delivery became a very dominant principle. It was seen as the key to improving service delivery as it could solve two related problems. The first problem was the fragmentation in service delivery. Taking away client contacts from the various back-offices and redistributing them over a small number of integrated front-offices would make life easier for citizens as it would reduce the number of stops a citizen had to make in his dealing with government. The integrated approach of offering clusters of services associated with particular problems also addressed the second problem in public policy: the non-use of services. This problem had been on the policy agenda for service delivery since the beginning of the 1990s and was reported on in various studies (BZK 1999; SZW 1999). It was widely felt that if a policy was adopted to alleviate some hardship for a particular group in society, then efforts should be made that the facilities offered actually benefit the target group. Various studies showed that especially the low-income groups turned out not to use the services intended for them, such as housing benefits, (e.g., BZK 1999; Koning et al. 1997; Smolenaars and Van Oorschot 1993). One of the reasons for the ineffectiveness of the low-income policy was the fact that people had to apply at different locations for the various facilities, which was a barrier and, furthermore, people had to be aware of the existence of a service in order to apply for the facility. Creating one-stop shops removed the physical barriers to applying for multiple services and, at the same time it also increased the likelihood that applicants became aware of the existence of the various relevant services as provided by the one-stop shop.

2 In English: 'Back to the future'. 
In 1999, an even more active stance to address issues of non-use and also to make life easier for citizens was adopted by the Ministry of the Interior. In the policy paper 'Achter het loket'3 (BZK 1999), the notion of pro-active service delivery was explored. Instead of waiting for citizens to apply for housing benefits, the government could often establish entitlement on the basis of information at its disposal through the Tax authorities and Municipal Personal Records Database, for instance. In some cases, there is no need for a front-office at all as some services are triggered by others. For instance, child allowances for the first newborn baby has to be applied for. For later born children application is unnecessary as the Municipal Personal Records Office will notify the agency responsible for the child allowance when the newborn baby is registered in his home town.

In line with other governments, most notably the English, the Dutch central government described its ambitions in 'measurable' objectives: in 2002, $100 \%$ of the public information was to be online. The target for transactional services was placed at $25 \%$ (BZK 1998).

\section{$2.2 O L 2000$}

The BIOS-3 policy white paper can be seen as the first outline of the Dutch e-Government policy. One of the prime results of this white paper was the establishment of the Public Counter 2000 project (OL2000) in 1996. A number of key ministries, most notably and most active, the Ministry of the Interior, and the Association of Netherlands Municipalities (VNG) collectively established a program bureau that was to pave the way for the broad introduction of e-Government. The strategy chosen was to adopt a bottom-up approach. The first stage of the OL2000 project was to consist of a relatively small number of pilot projects to be carried out by consortia of local authorities and businesses with limited project funding by the OL2000 Programme Bureau. Fifteen projects out of a set of 210 project proposals submitted by over 100 local authorities were selected as pilot projects for the first stage. The fifteen projects were organized in three categories: 'the elderly and disabled', 'housing' and 'know your civil rights' (Table 1).

The first stage of the OL2000 programme was relatively successful. It put service delivery clearly on the agenda and it created an awareness that a more client-oriented approach of public service delivery was feasible and desirable. Consumerist objectives (Bellamy and Taylor 1998) entered the public service delivery debates quite strongly, as witnessed, for instance in a study by the B\&A group in 1998 that showed that $66 \%$ of the Dutch municipalities were involved in some sort of project along the lines of the OL2000 initiative, compared to $33 \%$ in 1996 (B\&A et al., 1998).

The OL2000 project was not aiming at online service delivery per se. When the project started, the Internet did not offer the facilities required, the World Wide Web was just evolving, and also Internet penetration among citizens simply did not warrant a strictly online focus. What can be witnessed during the almost three years the project ran is that the development of online service delivery gradually did gain importance. Some of the projects that started offline, Meppel for instance, shifted their attention to online service development in the course of the project.

If we look at what was accomplished in terms of online services during the OL2000 project, the results are moderate. Even the pilots that aimed at developing integrated online (transaction) services, Enschede being the prime example, only managed to get a very small sample of services online. What was accomplished at best was a municipal website with much information on the various services offered by the municipality (Meppel). The integration of services fell short in most cases.

3 In English: 'Beyond the counter'. 
Table 1: OL2000 projects ${ }^{4}$

\begin{tabular}{|c|c|}
\hline Project & Aim \\
\hline \multicolumn{2}{|l|}{ Real estate: } \\
\hline Amsterdam region & Virtual real estate information kiosk aimed at businesses \\
\hline Den Haag & Real estate information at a city district level \\
\hline Nijmegen & Virtual and physical integrated desk offering real estate services \\
\hline Tilburg & $\begin{array}{l}\text { Data warehouse (GIS) to support front-office workers in the city's district } \\
\text { counters }\end{array}$ \\
\hline Tytsjerksteradiel & $\begin{array}{l}\text { Central integrated desk for real estate information (Tytsjerksteradiel spans a } \\
\text { very large geographical area, but has relatively few inhabitants) }\end{array}$ \\
\hline \multicolumn{2}{|l|}{ Elderly and disabled: } \\
\hline Aalburg & Information Kiosk for elderly and disabled \\
\hline Almelo & $\begin{array}{l}\text { Integrated service desk in which various semi-public and private service } \\
\text { providers in the welfare and health domain work together with the municipal } \\
\text { welfare department }\end{array}$ \\
\hline Alphen a/d Rijn & $\begin{array}{l}\text { A welfare service centre using expert system technology to support the intake } \\
\text { of welfare clients }\end{array}$ \\
\hline Eindhoven & $\begin{array}{l}\text { Integrated service desk in a local community featuring welfare, building and } \\
\text { housing, and social affairs services }\end{array}$ \\
\hline Emmen & $\begin{array}{l}\text { Integrated desk for housing, welfare and care; at first aimed at public services, } \\
\text { later also at semi-public and private services }\end{array}$ \\
\hline Utrecht & Virtual care-counter \\
\hline \multicolumn{2}{|l|}{ Know your civil rights: } \\
\hline Delft & $\begin{array}{l}\text { Integrated counter for immigrants/newcomers to the city of Delft. } \\
\text { Cooperation between city, police, and immigration services }\end{array}$ \\
\hline Enschede & $\begin{array}{l}\text { A virtual counter offering a wide variety of services in the domain of building } \\
\text { and housing }\end{array}$ \\
\hline Leiden & A virtual place for youngsters to hang out \\
\hline Meppel & $\begin{array}{l}\text { City website and a call centre offering basic information about } \\
\text { Meppel public services }\end{array}$ \\
\hline
\end{tabular}

Yet, at the turn of the century, the OL2000 project was internationally seen as an advanced project with an ambitious aim: the creation of a nation-wide network of one-stop shops. The strong emphasis on integrated service delivery, the high level of involvement in improving service delivery amongst municipalities and other public agencies, especially online, and the favorable starting position all contributed to high ranks for the Netherlands in international benchmarks at the time (Accenture 2001; CGEY 2002).

\subsection{Front office dominance}

The policy initiatives in the Netherlands up to the turn of the century show some interesting aspects that can help explain why the developments later turned out to have progressed slower than anticipated. In policy documents ever since the early 1990s, improving services for the benefit of the

4 A detailed account of these projects can be found in Lammers \& Lips (2000). 
public had been a primary motivation for e-Government plans and projects. Government efficiency hardly played a role in the discussions in the second half of the 1990s. This contrasts with other countries, most notably the US, where efficiency was a driving force.

The emphasis on integrated service delivery influenced the way online service delivery development was undertaken. Instead of focusing on large volume services to gain quick wins, many service providers (mostly municipalities) concentrated on defining demand patterns, combining services and (re)defining workflows associated with the various services. Since defining demand patterns, apart from the obvious ones related to life events, turned out not to be easy, the visible progress in getting services online was slow. The stakes were set fairly high, in retrospect maybe too high for the state of the art.

A third point to note is that, from the start of the e-Government plans, there had been a strong emphasis on creating front-offices without disturbing the back-offices too much. Again, this is in contrast with development strategies elsewhere. In the US, for instance, the federal government had, at that time, adopted the strategy to first re-engineer the back-offices before addressing the front-offices (Lips 1998).

The explanation for the emphasis on the front-office in the Netherlands can be found in two directions. The first explanation relates to the lack of political power of the policy makers. The e-Government policy discussed had been designed mainly by the central government (with the Ministry of the Interior as the principal agent) and promoted by an agency at arm's length of the ministry, the OL2000 Programme Bureau. The policy aimed at all levels of government, but in practice the main actors with respect to service delivery were the local authorities (municipalities, the police districts, the fire brigade districts etc.). Although the importance of back-office reform was acknowledged by the developers of the e-Government policy, they had, in fact, little to say about how local authorities should implement the service delivery outlined in the policy papers. Hence, the first policy papers focused on the front-offices without addressing the consequences for the back-offices in too much detail.

The second explanation derives from the fact that the silo structures in policy development as well as in service delivery were not seen as a serious problem in itself, but as an almost necessary effect of specialization. From the perspective of the citizen with more demanding problems, it would often have been more fruitful if the various policy sectors had co-operated and approached societal problems in a more integrated (or holistic) fashion. However, since many problems are complex in themselves, they require experts, giving rise to many agencies, each addressing tiny aspects of the public interest. The idea embedded in the e-Government policy papers was to shield the citizens from the complexity of the back-offices by creating front-offices that offer integrated services. The back-office reform that was deemed necessary would follow later once the merits of integration were established. It was hoped that this pragmatic approach would prevent all sorts of power struggles and reorganization problems within the back-offices. Not addressing organizational reform and instead primarily focusing on the front-offices was an effort to reduce the complexity of developing online services.

The fourth point to note was the strong reliance on ICT to enable the changes outlined. The first policy papers were produced in a period when IT costs were dropping, the Internet started to become available to society at large, and IT was seen as the panacea to create a 'government that works better and costs less' (Office of the Vice President 1993). At the very least, IT would enable improved service delivery to citizens (Lenk and Traunmüller 2002). After all, the separation of frontoffice from back-office is only possible through the introduction of ICTs and integrated (online) service delivery very much depends on advanced ICT support of the civil servant in the front-office. Of course, this is even more applicable to online service delivery where the citizens must somehow manage by themselves. 


\section{The present}

\section{I Service delivery at the national level}

What has happened since the turn of the century? Does the Netherlands still have its position as a European forerunner in e-Government in 2004? E-Government is being developed on all levels in the state: national, provincial, and local. The accomplishments of public agencies in developing electronic services, unsurprisingly, depend on the scale at which they operate (Leenes and Svensson 2004, 2005). On the national level, some impressive progress has been made. Large nationally operating government agencies (with large resources) have introduced fairly advanced e-Government applications. ${ }^{5}$ The Tax and Customs Administration, for instance, have a number of high volume online services in operation. Most notable is the Sagitta system, the customs and excise system which handles a large percentage of all goods declarations on imports into the Netherlands. Less successful, but still a good example of e-Government, is the electronic filing of income tax returns. In 2002, the tax office received 3.9 million electronic returns, which is $57 \%$ of the total number. Around $60 \%$ of them were filed by floppy disk, the rest by modem. In 2006, income tax returns for employees can be filed via the internet, whereas of January 2005, all Dutch businesses have to file their VAT returns online.

Another internationally well-known example of advanced electronic services is the car registration system offered by the RDW Centre for Vehicle Technology and Information. This system allows car dealers to register cars they sell electronically. Citizens can either go to a car dealer or the Post Office if they need to register their car (only required upon the purchasing of a car). The RDW is in effect a very large back-office without its own front-office. The student loan system offered by the Information Management Group (Informatiebeheer Groep), an independent administrative body, is also a good example of an advanced online public service. This service allows students to enroll in higher education and apply for student loans. Most of the interaction between student and the IB Groep takes place through the Internet.

A final example is the RINIS system, a network for information interchange between agencies in the social welfare sector that interconnects IT systems on a sector basis. The CWIs Centres for Work and Income, for instance, exchange information with their sector centre, which then routes the necessary information to other relevant agencies, possibly in other sectors, such as the tax sector. It resembles the well known Belgian Crossroads bank (Robben 2001).

\subsection{E-Government on the local level}

On the local level, which not only comprises the local authorities but also the police districts (25 in the Netherlands), the fire-fighter districts, ambulance regions, and some other public service providers, the picture is less bright.

On the municipal level, a number of distinctions can be made that show striking different approaches and effects. The first difference is between cities that took part in the OL2000 programme and those that did not. After the first phase of the OL2000 project (1997-1999), many of the OL2000 pilot

5 An overview of the state of the services used in the EU Commission benchmarks (e.g., CGEY 2004) in the Netherlands can be found at: <http://www.elo.nl/elo/english/egov/online_services/index.jsp>. 
projects more or less returned to business as usual, but three of them remained strongly committed to e-Government development: The Hague, Enschede, and the cluster 'Eindhoven/Helmond'. These cities were part of smaller follow-up pilots run by, for instance, the Ministry of Housing, Spatial Planning and the Environment. In 2001 they were enlisted in the so-called SuperPilot project (2001-2004). This project aimed to give the development of electronic online services an impulse by investing a considerable amount of central government money in a small number (three) of prospective pilot projects. Each of the three SuperPilots received EUR 2.7 million matching funding to develop online services. The results obtained in these pilots could be disseminated to other municipalities during and after the SuperPilot.

Although all SuperPilots aimed at speeding up the local e-Services development, the three pilots have different foci. Enschede concentrated on getting a large number of services online and devising tools and techniques to do so. Eindhoven focused primarily on back-office reform. The Hague also placed considerable emphasis on the back-offices. An important accomplishment here is the development of a new citizen public records system. This system not only is the basis for a number of services, such as moving house, birth and marriage registrations, but it will also replace the various name/address databases in use in the various municipal departments. As the pilot project is nearing its end at the time of writing this paper, a final verdict with respect to its results cannot be given yet, but judging from the interim reports, presentations and demonstrations and private conversations with the project managers, the results are promising indeed. ${ }^{6}$ Whether the results are useable in other cities remains to be seen though. The three SuperPilot municipalities are all cities with more than 100.000 inhabitants. This means they belong to the relatively small group of large cities (see Figure 1 for a distribution in municipal size).

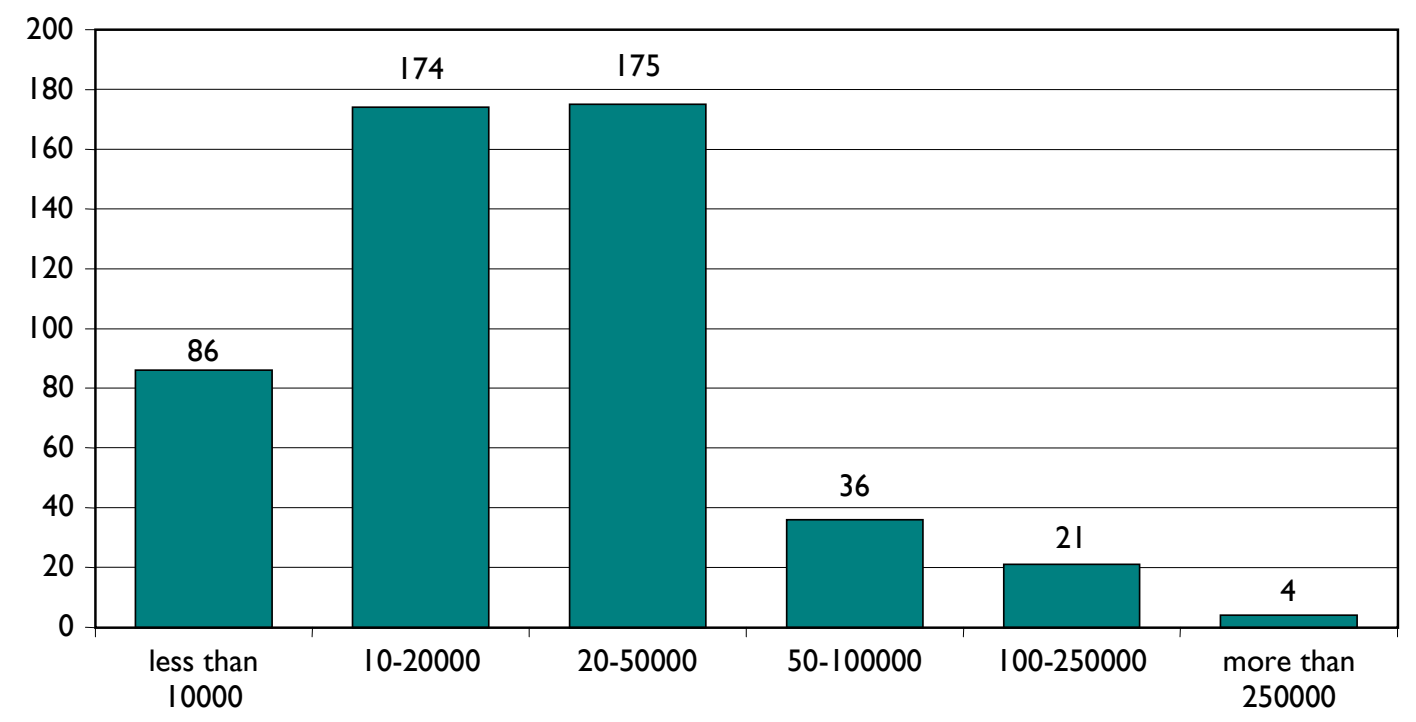

Figure 1: Municipal size in the Netherlands $(N=496)$.

Within the group of municipalities that did not participate in the OL2000 project, a distinction can be made between on the one hand, the small and medium sized municipalities, and on the other hand the larger cities. Not surprisingly, the large cities have the required resources to invest in electronic service delivery and, furthermore, they have the volumes of services that warrant these in-

6 See the SuperPilot website for more details on the pilots (in Dutch)

$<$ http://www.superpilots.nl/achtergrond/index.php>. 
vestments. This is less evident for the municipalities at the other end of the spectrum, which, as Figure 1 shows, accounts for over $50 \%$ of the municipalities. Here we find municipalities where IT support is handled by a handful of employees who have to do everything from installing desktop PCs to developing and maintaining municipal websites. Needless to say, in a town with 7,000 inhabitants most services have low frequencies.

\subsection{Measuring progress on the local level}

How are the municipalities doing? On the whole, e-Government at the local level is doing less well than at the national level. There are various indicators that warrant this conclusion. First of all, municipal web presence is a necessary requirement for electronic service delivery. It took until the end of 2003 for the last municipalities to launch their website. ${ }^{7}$ Figure 2 shows the growth in numbers of municipal websites over time. Instrumental in the process of developing local websites has been the 'VIND' product catalogue ${ }^{8}$ and a grant provided by the Ministry of the Interior for developing a municipal website and placing the 'VIND' catalogue on the website. VIND contains basic information about some 300 municipal products and services (what does the service amount to, what are the requirements, who do I contact, what is the procedure).

What the websites offer their users is measured by two Dutch national benchmarks for local eGovernment: the Webdam monitor ${ }^{9}$ and Advies Overheid.nl $l^{10}$. Both monitors measure data on eServices and show that e-Service maturity is not very high, especially for smaller municipalities (Leenes and Svensson 2005). Most municipalities offer a reasonable amount of information on the local services, often deriving from the VIND catalogue, some offer downloadable forms and only a few offer transactional services.

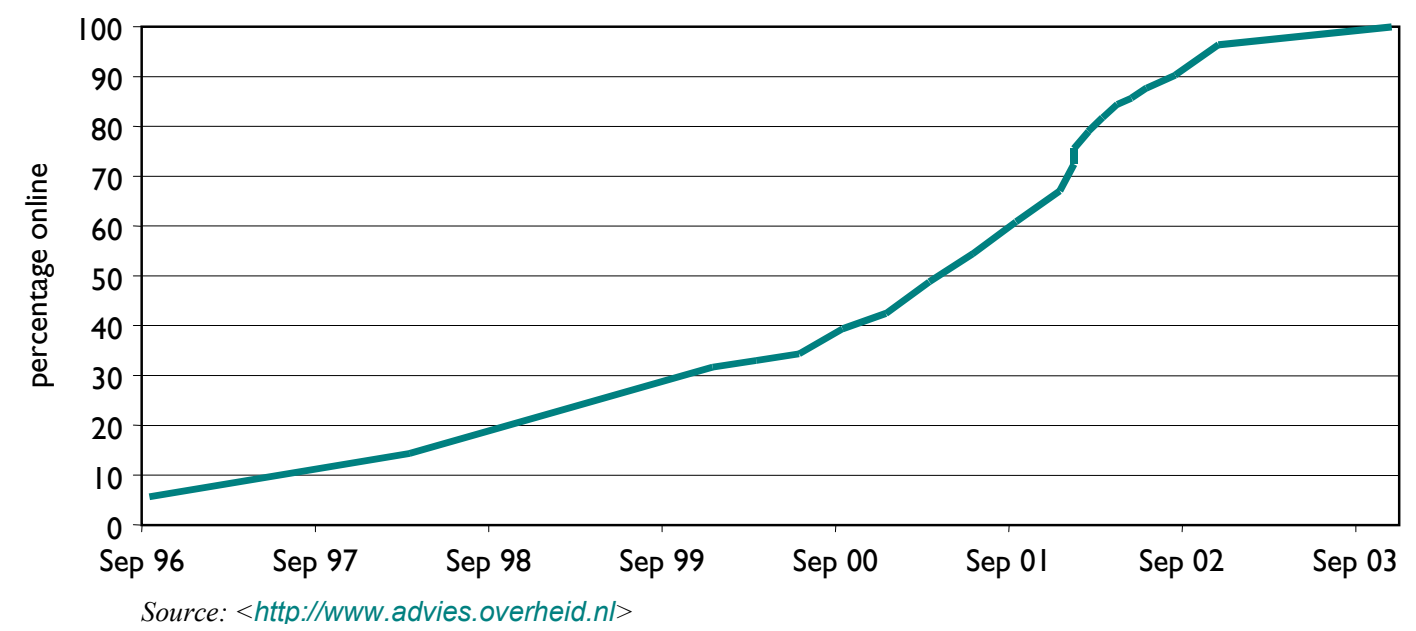

Figure 2: Proliferation of municipal websites.

7 By this I mean a website under the responsibility of the municipality, usually residing at $<$ http://www.name_of_municipality.nl $>$.

8 Vind' is Dutch for 'Find'.

$9<$ http://www.webdam.nl>.

$10<$ http://www.advies.overheid.nl>. 


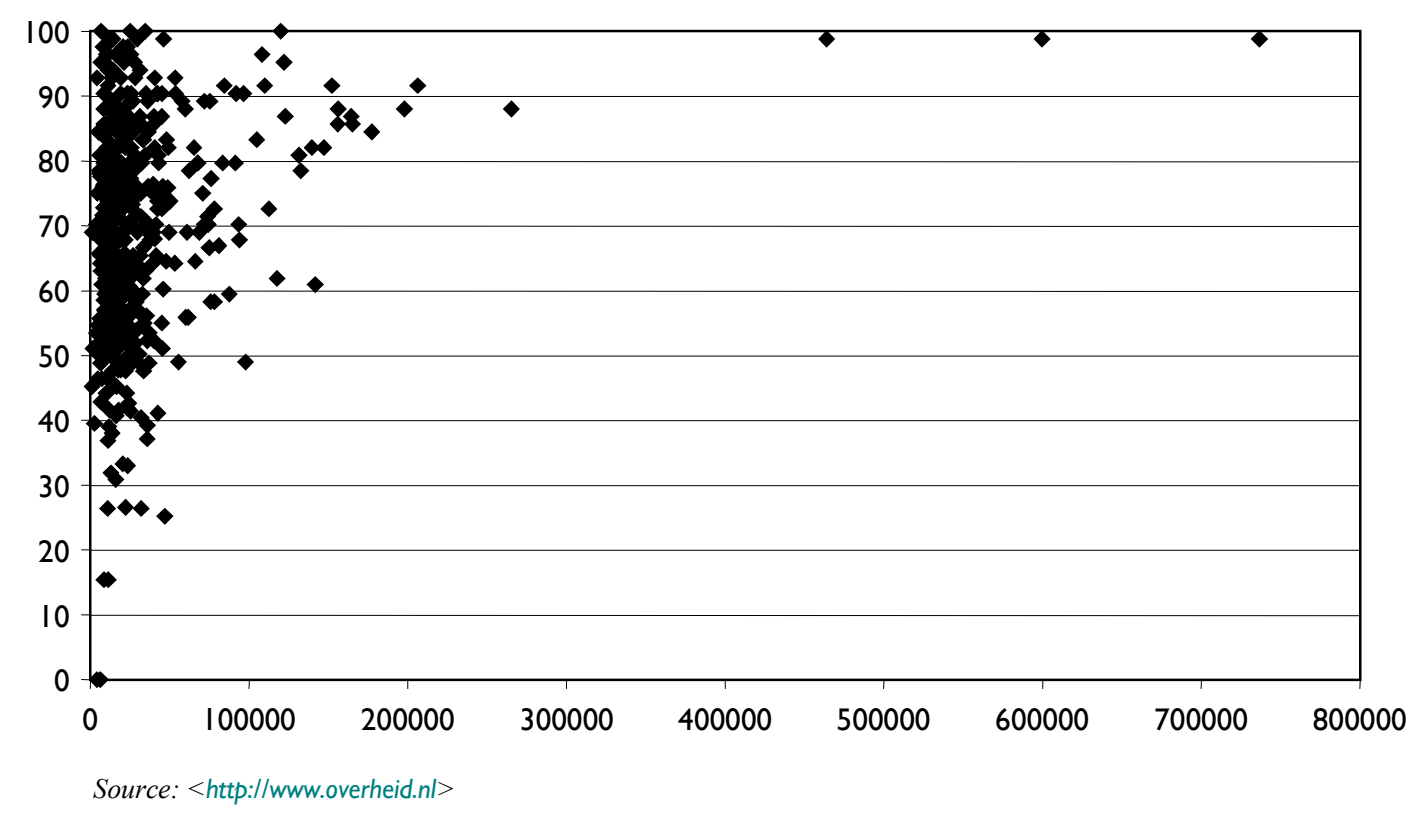

Figure 3: Municipal website maturity related to municipal size (vertical: website maturityll; horizontal: number of inhabitants).

A final indicator for the maturity of the local e-Government sites is citizen satisfaction. E-Services were rated as satisfactory by only $17 \%$ ( $1 \%$ rated the services as good) of the respondents in one study (Bongers et al. 2002). In a recent study by Advies overheid.nl, however, online services received a score of 6.4, whereas off line services were rated an 8.2 on a 10-point scale, with 10 standing for the maximum positive score (Advies Overheid.nl \& BZK 2003).

Notwithstanding the rhetoric of the policy white papers, it appears that implementing local e-Government turns out to be tougher than anticipated, even though research commissioned by the Ministry of the Interior (NEI Arbeid en Onderwijs 2000; Advies Overheid.nl \& BZK 2003) tries to create the impression that the goals have been achieved, albeit somewhat behind schedule. ${ }^{12}$

\subsection{The Netherlands compared to other EU countries}

Local authorities appear to do worse than the national agencies, but how do the Netherlands as a whole compare to other countries? This is even more difficult to assess than a comparison of accomplishments on a national scale due to the significant differences in the institutional make-up of the different countries, and the differences in services offered and their requirements, to name a few issues. Having said this, a look at international benchmarks may give some idea of the relative po-

11 Advies Overheid.nl scores government sites on the basis of a questionnaire with some 50 questions on usability, general appearance, city management information, services, and participation. The total score is the average of the scores on these five aspects and rates from 0 to 100 .

12 The methodology of these and other benchmarks, such as Accenture (2001, 2003, 2004), CGEY (2002, 2003) are troublesome and the conclusions are hard to interpret. See for instance Aichholzer (2002). For a discussion on the quality of benchmarks and for a comparison of a large number of them, see Janssen et. al (2003) and Rotthier (2004). 
sition of the Netherlands in Europe. There is a multitude of international benchmarks compiled, for instance, by consultancy firms (such as Accenture, CGEY, Deloitte, RAND), international organizations (OECD, UN, EU), and national agencies (Office of the e-Envoy). These international benchmarks show slightly different results but in most the Netherlands has slid back in rank over the years (Accenture 2003; CGEY 2004). On the new indicator introduced in the monitor of the European Commission, the number of public services fully available online, the Netherlands not only scores very low, but also progress of getting services online is slower than in most other EU countries (CGEY 2004).

Another indicator that the Netherlands is doing not too well is the fact that the UK, which was the Dutch role model with respect to goals, has moved forward its goals of offering public services online, whereas the Dutch have pushed them back. The current Dutch aim is to have $65 \%$ of all services (national, provincial, local) online by 2007 . The UK target of all services available electronically was moved forward from 2008 to 2005. Although this does not tell us much, since the original goals were set to get people moving, and moving them forward may be understood as a way to step up the pace. However, the fact that the UK ranks well above the Netherlands in the EU benchmark may be a sign that they indeed move harder.

Although hard conclusions with respect to the precise position of the Netherlands in comparison to other countries cannot be drawn on the basis of this limited discussion, it seems safe to conclude that the Netherlands is no longer at the top of the list. Why?

\section{Possible causes}

What has been shown so far is that there are several good examples of e-Government on the national level, whereas the local level performs less well. Although, at the national level, some highvolume services can be found, the local level is the level that matters most to the public, as it accounts for roughly $70 \%$ of the public services (Lips 1998). Below, probable causes for the relatively slow development on the local level will be discussed.

In order to understand the developments on the local level, the institutional make-up of the country has to be taken into consideration as this influences the division of labor and power between national and local levels. The Netherlands is a decentralized, unitary state (Jong and Schuszler 1999), combining centralized, hierarchical control by the central government with delegation of authority to local governments: provinces and municipalities. The latter is the more important with respect to citizens. The Dutch municipalities have their own constitutional responsibilities in policy development as well as in policy execution. They have the power to raise taxes and develop policy in areas not restricted to the national level by law. Of the EUR 36 billion municipalities have at their disposal annually, $54 \%$ can be used for local policy, the rest is earmarked for joint governance policy and national policy. Joint governance services can be found in areas such as social welfare. In these cases the policy is mainly set, and paid for, by the central government. The implementation is carried out by the municipalities, who can also add their own provisions, to be paid for by themselves, to the service. Service delivery based on strictly national policy concerns such services as driver's licenses. These services are same all over the country, though the service fee to be paid for by the citizen may vary. A passport may be cheaper in one city than in another. Interestingly, citizens can not choose where to obtain one. They are bound to their city of residence.

The types of services provided by local authorities has a strong bearing on what can be accomplished with respect to e-Services. Developing these for national policy is relatively easier than for local 
policy. At least, the total cost may be lower as services based on national policy can be developed once, and deployed everywhere. But then, why do we have a local service in the first place?

Centralization versus decentralization has played an important role in the debates on the organization of the Dutch state (Toonen 1987). The reasons for granting the municipalities a high degree of autonomy derives from a need for democratic control and participation in policy making; the idea is that local problems are best addressed locally. Another reason for the strong role of local authorities in policy execution and service delivery is a practical one. Local service delivery is convenient for citizens, especially for services that require people to appear in person. Also in cases where application forms could equally well be returned by mail, however, people find it convenient to either fill in the form at town hall or have the form checked by a civil servant before submission.

At least, this was the case in the offline world. In the online world, where in principle every form and every electronic brochure is at one's fingertips and intelligent forms can check the input on the fly, the municipal office is no longer the obvious partner for doing business with government. The (physical) barriers imposed by time, and distance no longer play a role, hence, for online services, local authorities are no longer necessarily the obvious places for service delivery. <http://www.amsterdam.nl> is not more convenient, nor logical, than <http://www.passport.nl $>$ for citizens to renew their passports.

The development of online service delivery and the extended use of ICTs in the process, could spur the modernization of government (Lenk and Traunmüller 2002). The structures of the state, the way in which and the location where policy is developed and executed and where service delivery takes places may need to be reconsidered in the light of the characteristics of ICT, such as horizontalization, deterritorialization, and virtualization (Frissen 1998). However, what we have witnessed up to now is that, in the development of electronic government, the institutional structures and procedures of the traditional, physical government are taken as starting points - perhaps as a conscious choice to maintain established power bases. This means that the offline service providers, often even without giving it a second thought, are taken to be the natural candidates for online service delivery as well. This may prove to be nothing more than paving the existing dirt roads, a phenomenon that is often seen in other domains as well (Hammer 1990), that prevents us from making the most of ICT.

In any case, ever since the conception of e-Government, both in policy documents and in actual practice, it has been assumed that each offline public service provider would develop online versions of their own services. The effect is, of course, that every municipality develops its own website and its own online services. Even without looking at these websites and services, it is safe to assume that many wheels are reinvented in the process.

\section{I A role for the national government?}

What can be done to help local governments to improve the efficiency of the e-Services development? The national government could play various roles in this respect. It could summon local authorities to reorganize their processes and streamline their policies. This requires central government to take an active role and indulge in steering and control of local affairs. This is an approach that is taken in some countries, such as the UK, to a certain level. I will discuss the feasibility of this option in section 4.1.1. Another role of central government could be to take care of the basic infrastructure (facilities, legislation, etc.) that benefits all service providers. This option, and the problems encountered, is discussed in section 4.1.2. A third role for central government could be to take an active lead in the development of e-Services for local governments. This option is discussed in section 4.2.1. 


\section{I.I Limited options for central steering and control}

At present, there are limited options to change course and redistribute tasks and responsibilities, unless these changes come from the local authorities themselves. The central government, as a result of the local autonomy, has limited choices for steering and control with respect to tasks currently assigned to, or taken on by, local authorities. The central government can tell local authorities how to operate concerning a limited number of services: namely, those services for which the central government is prepared to pay. If the services are paid for by the municipality, or through the general budget for local authorities, control by the central government is much more limited. Getting municipalities to act contrary to their own design causes much heated debate and is therefore often avoided to not disturb the fragile balance between the different government layers. Hence, given the current political climate, central government can do little else than produce white papers suggesting local authorities to adopt e-Government, provide funding for pilot projects that run on a voluntary basis, and hope for the best. Since budgets for pilots have been relatively limited, the effectiveness of a national e-Government policy for local authorities therefore depends on the strength of the arguments brought forward in the white papers and the willingness of local authorities to take up e-Government. In this respect, a strong e-Government champion could support the impact of policy white papers. Whereas the UK has its e-Envoy and the support of the Prime Minister, there has been no strong e-Government champion in the Netherlands. Instead, since the mid-1990s, eGovernment has been the responsibility of ministers with very limited resources and hardly any staff and political power. This means that, in persuading other ministries and other government agencies to invest in e-Services development, the minister's weight, and hence influence, is usually limited. This distribution of powers within government also reveals the lack of real political support for e-Government. Real-world policy issues, e.g., healthcare, prevail over government modernization.

\section{I.2 Neglect of basic infrastructure}

Apart from direct steering and control, the central government can also take care of basic facilities that benefit all parties involved. The construction of an electrical power infrastructure, roads, waterworks , etc., are clear examples of this role for central government of the not too distant past.

The Dutch central government has been slow in getting the basic infrastructure and legal frameworks necessary for the development of e-Government in place. At least some of the more frequent services require electronic identification and authentication. Local authorities have used the social fiscal number (SOFI number) as a means of identification, often in conjunction with date of birth or other personal data, for want of other means. Unfortunately, this manner of authentication is not allowed under Dutch law. Moreover, as the data used are easily obtained, it is also insecure and hence could undermine citizens' willingness to adopt new forms of public service delivery. This issue can only be dealt with by the national legislator as it determines the means of identification for public services. Although the issue is on the agenda since the mid 1990s, there still is no proper solution available. There is no electronic identity card in the Netherlands, and introduction before 2006 is not very likely. The implementation of EU directives on electronic and digital signatures was only completed in the summer of 2003, which means that this kind of service infrastructure has also received formal status only recently. Up to the introduction of the Electronic Signatures Act, electronic signatures had no formal status. As the act primarily applies to the private sector, separate legislation for the public sector was needed as well. This came into being in the Spring of 2004 by the enacting of the Digital Administrative Communications Act, which governs the electronic 
communication and transactions between government and businesses and citizens. ${ }^{13}$ This legislation not only paved the way for binding electronic public services (decisions, such as permits and grants), it also set out the rights and obligations of both citizens and government agencies with respect to the use of e-Services: citizens nor government agencies can be forced to adopt e-Services, but when they adopt them, the transactions are legally binding.

Other crucial e-Government building blocks were also taken on fairly late. An example is the Government Transactional Portal ${ }^{14}$. The Government Transactional Portal is to be an electronic PO Box for businesses for fulfilling their legal obligations in areas such as customs, taxes, and social security. ${ }^{15}$ The Belgian Crossroads bank (Robben 2001) and the UK Government Gateway, with a similar functionality, were developed much earlier. The development of these Gateways involves many players, both public (ministries and other government agencies) and private (businesses and business associations). In Belgium and in the UK, a single agency was made responsible for the gateway, and the required legislation to pave the way for them was established by one or a few government agencies. In the Netherlands, consensus building and voluntary participation of all parties involved is required (the Poldermodel). This makes it a time-consuming process, and hence not only the late start of developing the OTP poses a problem, but also the time span required to make it fully operational.

A conclusion at this point seems to be that the central government's role with respect to local eService development on the one hand necessarily seems to be limited due to local autonomy. On the other hand, we see that where the central government has a genuine role, it does not make a strong impression. These observations only partially explain the relative slow progress on the local level. A number of the causes can be found on this level itself.

\subsection{Problems at the local level}

On the local level most problems can be grouped in three categories; local authorities are unable, unwilling, or not allowed to implement e-Services (Hoogwout 2003; Kraayenbrink 2002). The roots of these three types of barriers can be found in institutional, economic, political, and legal factors.

\subsection{Local inability}

Local authorities are unable to implement e-Services on a scale required by the e-Government policy white papers. Dutch e-Government policy adheres to the local autonomy and stimulates local authorities to develop their own e-Services. As it is, the average municipality delivers several hundreds of services (Enschede, for instance, has descriptions of over 500 services in their product catalogue). Many of these, as Hoogwout compellingly argued (Hoogwout 2001), are hardly ever used by citizens. Even the most popular ones are relatively low-volume services (a passport once every 5 years for $70 \%$ of the population, a driver's license once every 10 years for $60 \%$ of the population). Therefore, on the one hand, there is in effect relatively little to gain by implementing online services for an individual municipality, whereas the costs of completely embedding the

\footnotetext{
13 The Wet bestuurlijk elektronisch verkeer [Digital Administrative Communications Act, my translation], which supplements the Algemene wet bestuursrecht [General Administrative Act].

14 In Dutch: Overheidstransactiepoort (OTP).

15 See, for instance, Arendsen \& Van Engers (2004) for more information on this project.
} 
service delivery in the back-office IT infrastructure are considerable. From an economic perspective, developing online services is not a feasible option for a large majority of the Dutch municipalities. Since half of the Dutch municipalities has fewer than 20,000 inhabitants, the burden of developing tens or hundreds of transaction modules will simply be beyond their capacity. This may well be an explanation for the low scores of small municipalities on the national benchmarks discussed earlier. Many local authorities simply do not bother to invest heavily in e-Government: it would not make sense.

There are different ways to solve this dilemma besides doing the bare minimum. One of the options is to increase economies of scale by joining efforts and co-develop services with other (similar) municipalities. Although there are examples of this development model (see section 5), they are scarce. Another option would be that either the central government or the market steps in. To start with the latter, this was in a sense the model envisioned by the drafters of the BIOS-3 white paper. Local authorities were to team up with businesses and enterprises to jointly develop services. The idea behind this was that services developed for one municipality could later be implemented elsewhere. There was supposed to be a market where private enterprises could recoup their investments made in the OL2000 pilot project. This model has not been very successful. Private enterprises were involved in a number of OL2000 pilots, but the level of investment of these enterprises in the projects has been very limited. They did not consider local e-Government to be a serious market. For many businesses the decision to only partake to a limited extent has been influenced by the fact that each local authority claims to be unique. It is easier to sell general purpose software, such as a word processor, than software that has to be tailored to local requirements, one reason being that customization is costly. Whether or not local authorities actually differ in their policy, the opacity of the market was such that not many IT developers entered the e-Government market at all. As a result, there are few off-the-shelf solutions.

This leaves the central government to lend a helping hand. It has done so by means of the VIND catalogue. This catalogue was commissioned by the OL2000 Programme Bureau as its development and maintenance was thought to be beyond the capacities of many individual municipalities. As mentioned before, VIND contains basic information about 300 municipal products and services. The VIND catalogue is successful in the sense that several hundreds of the Dutch municipalities have implemented VIND. However, it also shows an important problem of current local developments. VIND only provides general information and does not offer transaction services. In this respect, it is only a small step towards more mature e-Services. Municipalities at present are busy tailoring the basic information available in VIND to their own context (telephone numbers, particular requirements). This is a necessary step, but these efforts, which probably should have been made years ago, go at the expense of other e-Service developments.

A remarkable aspect of the VIND catalogue is that, although it offers a solution to one of the catch$22 \mathrm{~s}$ in e-Government development, it was also said to have been an unwarranted interference in the market by the central government (Hoogwout 2003). At the time VIND was developed, other product catalogues were also under development. These privately funded initiatives were set back considerably when VIND became available to municipalities free of charge. Worse, municipalities received financial incentives to implement VIND on their websites. This kind of central government intervention may prevent private enterprises from developing e-Service solutions for fear of history repeating itself. 


\subsubsection{Local unwillingness}

A second obstacle to local e-Government development relates to the economies-of-scale problem that underlies the unwillingness argument outlined above. Local authorities are unwilling to implement e-Services because of the lack of perceived benefits. The limited number of users of the various local services hardly warrant the investment of considerable amounts of resources. However, there is also a lack of political support for improving service delivery by means of implementing online services (Hoogwout 2001). Citizens are generally quite content with public service delivery as it is, and hence there is relatively little to gain in terms of citizen satisfaction. In other words, for the politicians responsible for e-Government on the local level, there seems to be little political incentive for promoting e-Services: e-Government does not win them any votes.

On the administrative level, not everyone is willing to build online services, either. Developing and implementing online services, if undertaken in earnest, requires process re-engineering, touches upon power structures, and people's roles and responsibilities, and is therefore a barrier (e.g. Grönlund 2000).

\subsubsection{Local disallowance}

A third barrier to local e-Government development arises from legal obstacles. Local authorities are not allowed to implement e-Services because current legislation is not tailored to electronic interaction or simply prevents municipalities from implementing certain services. An example of the latter is the lack of the means for identification and authentication addressed in section 4.1.2. Legal obstacles also arise as part of national legislation. The Land Registry Act, for instance, contained provisions that prevented local authorities from including land registry data (property ownership, for instance) in their e-Service modules, even though they had electronic access to these data and citizens could obtain the data at the physical desk free of charge. 


\section{The future}

In the previous sections, I have sketched but a few of the problems on the road to fully mature eServices. They show the general areas of concern of e-Government development at the local level in the Netherlands. The problems and causes sketched, however, will probably sound familiar to readers outside of the Netherlands just as well.

What emerges from the previous sections is that the goals set in the various policy papers since the mid 1990s are ambitious. The road to realization, especially at the local level, however, is paved with roadblocks of various sizes and shapes. What to do to remove them?

\section{I Economies of scale}

Many of the problems outlined stem out of a common cause: the limited scale at which local eServices are developed and implemented. In a sense it is odd that this appears to be the major problem hampering e-Service development as many services offered on the local level are similar all over the country. Burglary in my home town Deventer is governed by the same legislation as one in Maastricht or Amsterdam. Yet, in one police district burglary can be reported online, whereas in another it cannot. The reason for this is simple. The police districts are autonomous in their ICT developments, and, for one reason or another, some districts chose to develop online services for reporting crime, whereas others did not. Why not develop-once-deploy-everywhere for these uniform services? This would seriously speed up developments and make better use of limited resources.

This requires one of two strategies: the mandatory (local) implementation of services, or an attempt to achieve economies of scale by voluntary cooperation of service providers. In the first case, an authoritative agency, for instance a ministry, orders the agencies lower in the hierarchy to adopt a particular service. Although this model does not really fit the Dutch consensus model, there are signs that the situation is changing. Not too long ago (February 2004), for instance, the Dutch Ministry of Justice has decided that all police districts are to implement online crime reporting services. A law to this effect has been submitted to parliament. ${ }^{16}$

The second model, that of achieving economies of scale, is more in line with the Dutch culture in public administration. Economies of scale can be achieved in various ways, one of which is joint development of common services. As plausible as the strategy may seem, however, it takes a lot of energy to get local authorities to see that there is indeed something to develop jointly (similar services), and to actually bring them together to join hands.

In Leenes and Svensson (2002) it is suggested that it is possible to join forces on many policy issues because there is less diversity in local policy practices than might be expected given formal local autonomy. Recently, this suggestion has been supported by Muijsers (2003) who has investigated the practice of municipal tree felling (logging) policies. His report supports the claim that many municipalities can benefit from uniting to develop such services, since over $60 \%$ of the municipalities make use of the same reference bylaw developed by the Association of Netherlands Municipalities for some of services investigated. The economies-of-scale problems facing local authorities in developing policy and services on top of them existed in the offline world as well.

16 http://www.webwereld.nl/nieuws/I7834.phtml. Wijziging van het Wetboek van Strafvordering (elektronische aangiften en processen-verbaal), Kamerstukken II, 200428 438,nrs 1-3. 
Therefore organizations, such as the Association of Netherlands Municipalities, stepped in to lend a helping hand. As there are no statistics on the number of municipalities using these reference bylaws, few people are actually aware of the striking similarities between municipalities. Hence, cooperation in the development of services, let alone the delivery of these services, is hardly seen in practice.

Some promising efforts are in the pipeline, though. At present, a group of local authorities have established a foundation for developing services with respect to building permits. They have applied for a start-up subsidy from the Ministry of Housing, Spatial Planning and the Environment, and are testing a shared service for the building permit procedure. People submitting building permit applications, mostly architects and project developers, do so at a centrally hosted service. This server takes care of filing the application and it assists the civil servants involved in the application process by means of a document management system and a workflow system which routes documents to the appropriate actors. Although the server is maintained at a central location, it has the look and feel of the website of the municipality where the particular application is filed.

This shared service model may be applicable in other domains as well. This is one of the reasons why it was recently embraced by EGEM, a newly established joint venture of the Ministry of the Interior and the Association of Netherlands Municipalities to aid municipalities in e-Service development. ${ }^{17}$ It took over the project management that up to the summer of 2004 was done by a large municipality (Rotterdam) and a consultancy firm. Also InAxis ${ }^{18}$, a central government supported program for innovation in the public sector, and Gemnet ${ }^{19}$, an organization that offers public administrations secure communication services, are exploring and developing shared services.

Another, even more drastic approach to service delivery can also be witnessed. The small town of Ten Boer (7,150 inhabitants) just north of the city of Groningen (179,000 inhabitants), has decided to outsource service delivery altogether and instead only focus on policy development. The delivery of Ten Boer's services in the near future will be handled by the city of Groningen. This means that Groningen implements their own policies for its own citizens, and Ten Boer's policies for Ten Boer inhabitants. ${ }^{20}$

\footnotetext{
$17<$ http://www.egem.nl $>$.

$18<$ http://www.inaxis.nl>.

$19<$ http://www.gemnet.nl>.

20 This project received a project grant from the InAxis programme $<$ http://inaxis.nl $>$.
} 


\section{Conclusion: A critical note}

In this brief paper, I have described a part of the history of e-Government development in the Netherlands and I have shown that development lags behind expectations and also behind developments in other European countries. Development on the local level primarily seems to be hampered by the size of the municipalities involved. Hence, the main obstacle in the development process relates to lack of economy-of-scale. I have hinted at some developments that address the scale problem: more central steering and control and joint development. These approaches may indeed help pull the Dutch e-Government boat afloat. But before placing all bets on them, it may be useful to step back a little and consider the assumptions underlying the present analysis, and the solutions presented. It was inspired by the rhetoric in the e-Government policy white papers. In these papers, e-Government is presented as a solution to many problems facing public authorities and their relation with citizens and businesses, not unlike the miracles thought to be generated by GMOs, biotechnology, and more recently, nanotechnology. The notion of e-Government as described in the policy white papers, and also as understood by many people in the field, is value-laden: e-Government is good and more e-Government, i.e., more online services, more citizen interaction, more citizen participation, is better. Targets for online service delivery are set without taking into account the desirability of these kinds of services from the perspective of citizens and civil servants or the practical capabilities of the organizations involved. It is assumed that citizens want online service delivery. And although this may be the case for many services, it is certainly not the case for all. Take for instance online declaration to the police. The SIBIS 2002 study shows that $83 \%$ of the EU-15 population would not prefer to use the internet for online declarations to the police, whereas only $17 \%$ does prefer the internet for this service (SIBIS 2002). Online announcement of a change of address is only preferred by $43 \%$ of the EU-15 and $36 \%$ of the NAS population. These numbers may change when facilities are in place and people become accustomed to their use, as happened with cash dispensers (ATMs) in the 1980s and 1990s. Many people at the time said they preferred standing in line indoors and being served by bank employees over using these machines. History showed reality to be different. In public service delivery there are various services for which people prefer face-to-face contacts, such as social security services. Can it be guaranteed that the traditional services will remain to exist besides online services, or do we inevitably move towards a real electronic government in which all interaction is handled by computers? How does this relate to individual problems that may require individual solutions?

Next to different preferences with respect to types of services, there are also various digital divides to be taken into account. The younger generations, for instance, are growing up in an online world. The Internet is their home base and the first place, and in many cases, unfortunately the only place, where they look for information and services. For the elderly, the story is different, they have a hard time coping with the online world and prefer face to face contact over online contact. One can doubt whether the elderly share the idea of more e-Government is better embedded in the policy white papers.

Policy white papers, benchmarks, and to a certain extent also this paper, put pressure on local authorities to get their services online. If the pressure derives from an urge to improve service delivery, then one has to bear in mind that there are also other means to accomplish this goal. Local authorities may opt to improve their service delivery by increasing the level of personal care in the interaction with citizens, for instance by visiting them in their homes. Can such a local authority withstand the pressure imposed by the national benchmarks that are strongly biased towards online services? Is there sufficient debate on the actual merits of e-Government for citizens and public authorities? 


\section{References}

Accenture (2001), eGovernment Leadership: Rhetoric vs Reality - Closing the Gap: Accenture, $<$ http://www.accenture.com>.

Accenture (2003), eGovernment Leadership: Engaging the Customer: Accenture.

Accenture (2004), eGovernment Leadership: High Performance, Maximum Value: Accenture.

Advies Overheid.nl en Ministerie van Binnenlandse Zaken en Koninkrijksrelaties (2003), Publieke dienstverlening $55 \%$ elektronisch. Tweemeting van de elektronische dienstverlening van de overheid in 2002.

Aichholzer, Georg (2002), Benchmarking und Best Practice im Bereich e-Government. in: Maria A. Wimmer (ed.), Impulse für e-Government: Internationale Entwicklungen, Organisation, Recht, Technik, Best Practices, Wien: Österreichische Computergesellschaft, 181-191.

Arendsen, Rex, and Tom M. van Engers (2004), The role of e-Government in the reduction of information compliance costs, in: Roland Traunmüller (ed.) Electronic Government. Third International Conference, EGOV 2004, Zaragoza, Spain, August/September 2004, Proceedings. Berlin, Heidelberg, New York: Springer, 200-206.

B\&A group and Moret Ernst \& Young Management Consultants (1998), Naar een landelijke implementatie van de één-loketgedachte (Towards a nationwide implementation of the one-stop government shops), Den Haag/Utrecht.

Bellamy, Christine, and John A. Taylor (1998), Governing in the Information Age. Buckingham, Bristol, PA: Open University Press.

Bongers, Frank, Rens Vandeberg, Krijn Schuurman, and Christiaan Holland (2002), Burgers aan het woord: Oordelen en klachten over de elektronische overheid, Utrecht: Dialogic Innovatie \& Interactie.

BZK (Ministry of the Interior and Kingdom Relations) (1995), Terug naar de toekomst: over het gebruik van informatie en informatie - en communicatietechnologie in de openbare sector, Den Haag: Ministerie van Binnenlandse Zaken en Koninkrijksrelaties.

BZK (1998), Actieprogramma Elektronische Overheid, Den Haag: Ministerie van Binnenlandse Zaken.

BZK (1999), Voorbij het loket: over de mogelijkheden en onmogelijkheden van pro-actieve dienstverlening voor de Nederlandse Overheidsorganisaties, Den Haag: Ministerie van Binnenlandse Zaken en Koninkrijkrelaties.

CGEY (Cap Gemini Ernst \& Young) (2002), Online availability of public services: How does Europe progress? Web based survey on electronic Public Services, Brussels: EU Commission, DG Information Society.

CGEY (2004), Online availability of Public Services: How is Europe progressing? Fourth measurement, Brussels: EU Commission, DG Information Society.

Frissen, P. (1998), Public Administration in Cyberspace, in: I.Th.M. Snellen and W.B.H.J. van de Donk (eds.), Public Administration in an Information Age, Amsterdam et al.: IOS Press, 33-46.

Hammer, Michael (1990). Reengineer Work: Don't Automate, Obliterate. Harvard Business Review 90: $104-112$. 
Hoogwout, Marcel (2001), Leuker kunnen we het niet maken, maar willen we het wel makkelijker? Waarom overheden geen haast hebben met het verbeteren van de dienstverlening, in: Hein van Duivenboden en Miriam Lips (eds.) Klantgericht werken in de publieke sector: Inrichting van de elektronische overheid, Utrecht: Uitgeverij LEMMA BV, 149-166.

Hoogwout, Marcel (2003), Super Pilots, Subsidizing or Self-Organization: Stimulating E-Government Initiatives in Dutch Local Governments, in: R. Traunmüller (ed.) Electronic Government. Second International Conference, EGOV 2003, Prague, Czech Republic, Sept. 2003, Berlin, Heidelberg, New York: Springer, 85-90.

Grönlund, A. (2000), Managing Electronic Services - A Public Sector Perspective, London, etc: Idea Group Publishing.

Janssen, Davy, Sabine Rotthier, and Kris Snijkers (2003), Benchmarken van e-Government, Leuven: Algemeen secretariaat - Steunpunt Beleidsrelevant onderzoek Bestuurlijke Organisatie Vlaanderen.

Jong, H. M. de, and P. A. Schuszler (1999), Staatkunde Nederland in drievoud. Bussum: Coutinho.

Koning, H. E., T.A.M. Witteveen, Tweede Kamer en Algemene Rekenkamer (1997), Klantgerichtheid publieke dienstverlening, 's-Gravenhage: Sdu Uitgevers.

Kraayenbrink, Jeroen (2002), Back to the Future: Centralization on its Revival? Problems in the Current Organization of Public Integrated Service Delivery. in: R. Traunmüller and K. Lenk (eds.), Electronic Government - First International Conference, EGOV 2002, Aix-en-Provence, France. Berlin, Heidelberg, New York: Springer, 10-17.

Lammers, Kristel, and Miriam Lips (2000), Netherlands. in: Martin Hagen and Herbert Kubicek (eds.), One-Stop-Government in Europe: Results from 11 national surveys, Bremen: University of Bremen, 401-466, http://www.fgtk.informatik.uni-bremen.de/COST/reports/Netherlands.pdf.

Leenes, R.E., and J.S. Svensson (2002), Size Matters - Electronic service delivery by municipalities? in: R. Traunmüller and K. Lenk (eds.), Electronic Government - First International Conference, EGOV 2002, Aix-en-Provence, France. Berlin, Heidelberg, New York: Springer, $150-156$.

Leenes, R.E., and J.S. Svensson (2004), Electronic Services in a Decentralized State, in: Roland Traunmüller (ed.), Electronic Government. Third International Conference, EGOV 2004, Zaragoza, Spain, August/September 2004, Proceedings. Berlin, Heidelberg, New York: Springer, 496-502.

Leenes, R.E., and J.S. Svensson (2005, forthcoming), Local eGovernment in the Netherlands, in: Helmut Drüke (ed.), Local Electronic Government. An International Comparison. New York, London: Routledge.

Lenk, Klaus, and Roland Traunmüller (2002), Electronic Government: Where are we heading? in: R. Traunmüller and K. Lenk (eds.), Electronic Government - First International Conference, EGOV 2002, Aix-en-Provence, France. Berlin, Heidelberg, New York: Springer, 1-9.

Lips, A.M.B (1998), Reorganizing Public Service Delivery in an Information Age, in: I.Th.M. Snellen and W.B.H.J. van de Donk (eds.), Public Administration in an Information Age, Amsterdam etc: IOS Press, 325-339.

Muijsers, Koen (2003), Samen meer bereiken - Een onderzoek naar de aard en variëteit in gemeentelijke dienstverlening ten behoeve van schaalvergroting in de ontwikkeling van elektronische dienstverlening, Msc. Thesis. Enschede: University of Twente. 
NEI Arbeid en Onderwijs (2000), Publieke dienstverlening $25 \%$ elektronisch: Nulmeting inventarisatie van de elektronische dienstverlening van de overheid, Rotterdam: NEI Arbeid en Onderwijs.

Oakley, Kate (2000), Egovernment: an international study of online government, commissioned by Cables \& Wireless Communications, London: Cables \& Wireless Communications.

Office of the Vice President (1993), Reengineering government through IT, Washington DC: Government Printing Office.

Robben, Frank (2001), A model for Electronic Data Exchange in the Public Sector, in: Jos Dumortier, Frank Robben and Marc Taemans (eds.), A Decade of Research@ the Crossroads of Law and ICT, Gent: Larcier.

Rotthier, Sabine (2002), E-Government Policies, Strategies and Implementation: e-Government in the Federal Country Belgium, in: Roland Traunmüller (ed.). Electronic Government. Third International Conference, EGOV 2004, Zaragoza, Spain, August/September 2004, Proceedings. Berlin, Heidelberg, New York: Springer, 549-551.

SIBIS (Statistical Indicators Benchmarking the Information Society) (2002), Deliverable D3.1 General Population Survey Basic Data, IST-2000-26276.

Smolenaars, E., and W. van Oorschot (1993), Minimabeleid kampt

SZW (Ministerie van Sociale Zaken en Werkgelegenheid) (1999). met effectiviteitsproblemen. Sociaal Bestek 9. Terugdringen niet-gebruik van inkomensafhankelijke voorzieningen; pilots bestandsvergelijking, Den Haag: Ministerie van Sociale Zaken en Werkgelegenheid/Ernst \& Young Consulting.

Toonen, Theo A. J. (1987), Denken over binnenlands bestuur - theorieën van de gedecentraliseerde eenheidsstaat bestuurkundig beschouwd, 's-Gravenhage: VUGA. 


\section{Previously published manu:scripts}

ITA-0I-0I Gunther Tichy, Walter Peissl (12/2001): Beeinträchtigung der Privatsphäre in der Informationsgesellschaft. <http://www.oeaw.ac.at/ita/pdf/ita_0I_0I.pdf>

ITA-0I-02 Georg Aichholzer(12/2001): Delphi Austria: An Example of Tailoring Foresight to the Needs of a Small Country. <http://www.oeaw.ac.at/ita/pdf/ita_0I_02.pdf>

ITA-0I-03 Helge Torgersen, Jürgen Hampel (12/2001): The Gate-Resonance Model: The Interface of Policy, Media and the Public in Technology Conflicts.

<http://www.oeaw.ac.at/ita/pdf/ita_0I_03.pdf>

ITA-02-0I Georg Aichholzer (01/2002): Das ExpertInnen-Delphi: Methodische Grundlagen und Anwendungsfeld ,Technology Foresight“.

<http://www.oeaw.ac.at/ita/pdf/ita_02_0l.pdf>

ITA-02-02 Walter Peissl (01/2002): Surveillance and Security - A Dodgy Relationship.

<http://www.oeaw.ac.at/ita/pdf/ita_02_02.pdf>

ITA-02-03 Gunther Tichy (02/2002): Informationsgesellschaft und flexiblere Arbeitsmärkte. $<$ http://www.oeaw.ac.at/ita/pdf/ita_02_03.pdf>

ITA-02-04 Andreas Diekmann (06/2002): Diagnose von Fehlerquellen und methodische Qualität in der sozialwissenschaftlichen Forschung.

<http://www.oeaw.ac.at/ita/pdf/ita_02_04.pdf>

ITA-02-05 Gunther Tichy (10/2002): Over-optimism Among Experts in Assessment and Foresight. $<$ http://www.oeaw.ac.at/ita/pdf/ita_02_05.pdf >

ITA-02-06 Hilmar Westholm (12/2002): Mit eDemocracy zu deliberativer Politik? Zur Praxis und Anschlussfähigkeit eines neuen Mediums.

$<$ http://www.oeaw.ac.at/ita/pdf/ita_02_06.pdf $>$

ITA-03-0I Jörg Flecker und Sabine Kirschenhofer (01/2003): IT verleiht Flügel? Aktuelle Tendenzen der räumlichen Verlagerung von Arbeit. $<$ http://www.oeaw.ac.at/ita/pdf/ita_03_0l.pdf>

ITA-03-02 Gunther Tichy (11/2003): Die Risikogesellschaft - Ein vernachlässigtes Konzept in der europäischen Stagnationsdiskussion.

$<$ http://www.oeaw.ac.at/ita/pdf/ita_03_02.pdf>

ITA-03-03 Michael Nentwich (11/2003): Neue Kommunikationstechnologien und Wissenschaft - Veränderungspotentiale und Handlungsoptionen auf dem Weg zur Cyber-Wissenschaft. <http://www.oeaw.ac.at/ita/pdf/ita_03_03.pdf>

ITA-04-0I Gerd Schienstock (1/2004): Finnland auf dem Weg zur Wissensökonomie - Von Pfadabhängigkeit zu Pfadentwicklung. <http://www.oeaw.ac.at/ita/pdf/ita_04_0I.pdf>

ITA-04-02 Gunther Tichy (6/2004): Technikfolgen-Abschätzung: Entscheidungshilfe in einer komplexen Welt. <http://www.oeaw.ac.at/ita/pdf/ita_04_02.pdf>

ITA-04-03 Johannes M. Bauer (11/2004): Governing the Networks of the Information Society - Prospects and limits of policy in a complex technical system.

$<$ http://www.oeaw.ac.at/ita/pdf/ita_04_03.pdf>

ITA-04-04 Ronald Leenes (12/2004): Local e-Government in the Netherlands: From Ambitious Policy Goals to Harsh Reality. <http://www.oeaw.ac.at/ita/pdf/ita_04_04.pdf> 